\title{
Lorong Panjang Pelaksanaan Good Governance di Daerah
}

\section{Long Journey of Good Governance in Local Government}

\author{
Muhtar Haboddin ${ }^{1}$, Ahmad Imron Rozuli ${ }^{2}$ \\ Ilmu Pemerintahan, Universitas Brawijaya ${ }^{1}$, Ilmu Sosiologi, Universitas Brawijaya ${ }^{2}$ \\ muhtar_haboddin@ub.ac.id
}

\begin{abstract}
Abstrak
Artikel ini bertujuan mengungkap pelaksanaan good governance di daerah. Dalam praktiknya, good governance tidak mudah dilaksanakan. Memang, ada daerah yang berhasil. Namun, ada pula yang gagal. Ironisnya adalah kepada daerah yang terdepan menerapkan good governance, diujung akhir masa jabatan malah terlilit dalam kasus korupsi. Tidak hanya itu, tantangan terberat dari pelaksanaan good governance di daerah dalam adalah jaminan keberlanjutan dan komitmen politik yang rendah. Akibatnya, terkadang penerapan good governance ini terpinggirkan karena ganti pemimpin dengan agenda yang sama sekali berbeda dengan pendahulunya. Bisa juga karena alasan politis, yakni good governance tidak memberikan keuntungan secara personal bagi kepala daerah.
\end{abstract}

Kata kunci: good governance dan pemerintah daerah

\begin{abstract}
This article aims to describe the implementation of good governance in the region. In practice, good governance is not easy to implement. Indeed, there are areas that are successful and some failed. The irony is that the regions that are at the forefront of implementing good governance, at the end of the end of their term, are actually involved in corruption cases. Not only that, the toughest challenge of implementing good governance in the region is the guarantee of sustainability and low political commitment. As a result, sometimes the implementation of good governance is marginalized because the leader changes with an entirely different agenda from his predecessor. It could also be due to political reasons, namely good governance does not provide personal benefits for the regional head.
\end{abstract}

Keywords: good governance and local government

\section{A. Pendahuluan}

Apakah pemaknaan dominan tentang pemerintahan yang baik telah mengarah pada penjaminan kepentingan rakyat kita? (Pratikno, 2004:10). Good Governance bukanlah ide yang bebas nilai diterapkan pada semua konteks kehidupan politik dan pemerintahan (Cahyo Suyanto, 2002; 46). Dua kutipan tersebut saling terkait. Bila
Pratikno mengatakan pemaknaan good governance sangat dominan dalam kehidupan politik dan pemerintahan, tentu tidak bisa dibantah. Begitu pula, Suyanto mengatakan good governance tidak bebas nilai. Good governance lahir dari rahim ideologi liberalisme. Karena itu, yang disuarakan adalah bagaimana agar pemerintah dikurangi tugas dan fungsinya. 
Inilah yang menjadi semangat penyebarluasan gagasan good governance di seluruh penjuru dunia-utamanya di negara-negara yang sedang melakan transisi dari rezim otoriter-sentralistik menuju demokrasi-desentralisasi.

Semangat dan ideologi liberalisme yang tertuang dalam gagasan good governance menyusup secara halus dalam tatakelola pemerintahan daerah di Indonesia. Disadari atau tidak, para politisi, praktisi pemerintahan maupun ilmuwan berkontribusi dalam mengkampanyekan perlunya good governance diadopsi. Implikasikasinya adalah gagasan good governance menjadi isu penting dalam tatakelola pemerintahan daerah. Hal ini bermula ketika Indonesia mengalami transisi politik yang ditandai dengan hadirnya UU No 22/1999 tentang Pemerintahan Daerah. Secara substansi UU ini membawa dua perubahan besar dalam tata kelola pemerintahan daerah: demokratisasi dan desentralisasi. Demokratisasi memungkinkan terjadinya pemberian ruang bagi pelibatan berbagai aktor dan masyarakat dalam proses pemerintahan daerah. Sementara desentralisasi membuka ruang partisipasi dan penyerahan kewenangan dari pemerintah pusat ke unit pemerintahan daerah.

Kendatipun demikian dalam praktiknya, demokratisasi dan desentralisasi tidak mudah dijalankan secara beriringan dalam tata kelola pemerintahan daerah. Demokratisasi dan desentralisasi pada kenyataannya banyak mengalami rintangan dan hambatan dari apatur pemerintah daerah. Ruang partisipasi, pelibatan aktor non pemerintahan dalam tata-kelola pemerintahan daerah belum sepenuhnya bisa dipraktikkan. Bahkan, pada titik tertentu masyarakat sipil, media massa, dan perguruan tinggi belum bisa dijadikan mitra sejajar dengan pemerintaha daerah. Tidak hanya itu, sebagian pemerintah daerah dan aparatur birokrasi daerah masih menganggap dirinya sebagai aktor tunggal dalam penyelenggaraan pemerintah daerah. Bahkan, masih kita temukan pemerintah daerah yang tertutup, tidak transparan, tidak melibatkan publik dalam perencanaan pembangunan, perilaku nepotisme dalam rekrutmen dan penempatan pegawai, dan menjalarnya pungutan liar dalam penyelenggaraan pemerintah daerah.

Sederet kekurangan ini merupakan bukti betapa beratnya membangun good governance di daerah. Karena itu, tidak salah apabila Riswandha Imawan [2005;40] mengatakan good governance ibarat mimpi indah penghias tidur disaat rakyat semakin lapar. Pendapat Imawan merupakan nada gugat betapa sulitnya membangun good governance di daerah. Padahal ide dan gagasan pemerintahan yang bersih merupakan salah satu tuntutan reformasi politik 1998, hingga kini masih jauh dari harapan. Makalah ini akan dimulai dengan penjelasan makna dan nilai, kemudian dipaparkan problematika pelaksanaan good governance, hingga ketidakmampuan pemerintah daerah merawat secara berkelanjutan. Segala problematika tersebut membutuhkan jalan keluar melalui membangun good governance. Langkah selanjutnya adalah menarik kesimpulan.

\section{B. Pembahasan}

1. Makna dan nilai Good Governance 
Istilah "good governance" telah diterjemahkan dalam berbagai istilah, misalnya, penyelenggaraan pemerintahan yang amanah, tata-pemerintahan yang baik (UNDP), pengelolaan pemerintahan yang baik dan bertanggunjawab (LAN), dan ada juga yang mengartikan secara sempit sebagai clean governmene [Effendi, 2005;1]. Perbedaan penyebutan good governance menunjukkan bahwa konsepsi ini mengalami perkembangan sesuai dengan konteks dan lokalitasnya.

Pertanyaannya adalah apa yang dimaksud good governance? Good governance dimaknai sebagai tata pemerintahan yang dikelola secara bersama antara pemerintah, masyarakat sipil, dan pelaku usahawan/swasta [Tallo, 2003;13]. Pemaknaan ini lebih dekat atau sama antara konsepsi 'governance' ketimbang 'good governance'. Padahal antara 'governance' dan 'good governance' sangat berbeda dalam kajian ilmu pemerintahan. Governance berbicara aktor yang terlibat dalam pemerintahan, sedangkan good governance adalah nilai yang digunakan dalam penyelenggaraan pemerintahan. Sementara ilmuwan yang lain, mengartikan good governance adalah kemampuan pemerintah mewujudkan persamaan kedudukan antara sesama warga negara dihadapan hukum dan pemerintahan, di samping menjunjung tinggi hukum dan pemerintahan itu sendiri [Ali, 2000]. Sedangkan, Bank Dunia mendefinisikan good governance sebagai suatu penyelenggaraan manajemen pembangunan yang solid dan bertanggungjawab yang sejalan dengan prinsip demokrasi dan pasar yang efisien, penghindaran salah alokasi dana investasi, dan pencegahan korupsi baik secara politik maupun administrasi, menjalankan disiplin anggaran, serta mencipatakan legal and political framework bagi tumbuhnya aktivitas usaha [Mardiasmo, 2002;24].

Selanjutnya, ada juga yang memahami good governance sebagai upaya membuat agar pemerintah lebih bertanggungjawab (more accountable), transparan, dan responsif. Good governance tercipta tidak melalui perubahan dalam atau atas kehendak pemerintah semata, tetapi karena atas kehendak dan dorongan organisasi eksternal sejalan dengan meningkatnya kemampuan dan keterampilan masyarakat sipil dalam melakukan tekanan agar pemerintah menjadi lebih akuntabel [Effendi,2002;3].

Definisi menarik untuk dicermati karena menempatkan good governance sebagai konsepsi dari luar, dan kemudian diinjeksi dalam tubuh pemerintahan. Nilai-nilai good governance yang diinjeksi ke dalam pemerintahan adalah pertanggungjawaban, transparansi, dan responsif. Tiga nilai diharapkan agar pemerintah lebih baik kinerjanya dalam proses penyelenggaraan pemerintahan. Pertanggungjawaban, transparansi, dan responsif merupakan bagian penting dalam sistem pemerintahan demokratis. Pemerintah dituntut untuk bertanggungjawab terhadap segala kebijakan yang dibuat. Kebijakan yang dibuat itu harus transparan dengan melibatkan masyarakat sipil. Pemerintah yang terbuka merupakan jawaban atas tata kelola pemerintahan yang baik dan bersih.

Adapun nilai-nilai yang terkandung dalam good governance adalah sebagai berikut:

a. Partisipasi masyarakat: semua warga masyarakat mempunyai suara dalam pengambilan 
keputusan, baik secara langsung maupun melalui lembaga-lembaga perwakilan yang sah yang mewakili kepentingan mereka. Partisipasi menyeluruh tersebut dibangun berdasarkan kebebasan berkumpul dan mengungkapkan pendapat, serta kepastian untuk berpartisipasi secara konstruktif;

b. Tegaknya supremasi hukum: kerangka hukum harus adil dan diberlakukan tanpa pandang bulu, termasuk di dalamnya hukumhukum yang menyangkut hak asasi manusia;

c. Transparasi: transparansi di bangun atas dasar informasi yang bebas. Seluruh proses pemerintah, lembaga-lembaga, dan informasi perlu dapat diakses oleh pihakpihak yang berkepentingan, dan informasi yang tersedia harus memadai agar dapat dimengerti dan dipantau;

d. Peduli dan stakeholder: lembagalembaga dan seluruh proses pemerintah harus berusaha melayani semua pihak yang berkepentingan;

e. Berorientasi pada konsensus: tata pemerintahan yang baik menjembatani kepentingankepentingan yang berbeda demi terbangunnya suatu konsensus menyeluruh dalam hal apa yang terbaik bagi kelompok-kelompok masyarakat, dan bila mungkin, konsensus dalam hal kebijakankebijakan dan prosedur-prosedur;

f. Kesetaraan: semua warga masyarakat mempunyai kesempatan memperbaiki atau mempertahankan kesejahteraan mereka;

g. Efektifitas dan efisiensi: prosesproses pemerintahan dan lembagalembaga membuahkan hasil sesuai kebutuhan warga masyarakat dan dengan menggunakan sumbersumber daya yang ada seoptimal mungkin;

h. Akuntabilitas: para pengambil keputusan di pemerintah, sektor swasta, dan organisasi masyarakat bertanggungjawab, baik kepada masyarakat maupun kepada lembaga-lembaga yang berkepentingan.

i. Visi strategis: para pemimpin dan masyarakat memiliki perspektif yang luas dan jauh ke depan atas tata pemerintahan yang baik dan pembangunan manusia, serta kepekaan akan apa saja yang dibutuhkan untuk mewujudkan perkembangan tersebut. Selain itu mereka juga harus memiliki pemahaman atas kompleksitas kesejarahan, budaya, dan sosial yang menjadi dasar bagi perspektif tersebut [Hardjasoemantri, 2003;5].

Nilai-nilai good governance yang dipopulerkan Bank Dunia tersebut mendominasi perbincangan akademik selama beberapa tahun terakhir. Partisipasi, transpransi, penegakan hukum, konsensus, kesetaraan, efektif dan efisien, serta visi strategis dijadikan pijakan dalam penyelenggaraan pemerintahan Sedangkan, di Inggris good governance lebih spesifik lagi disebutkan yakni legitimasi, akuntabilitas, kompetensi, penghormatan terhadap hukum, dan hakhak asasi manusia [Pratikno,2005; 236]. 
Bila nilai-nilai good governance ini diinternalisasi dalam tata kelola pemerintahan daerah sudah bisa dipastikan wajah pemerintahan akan menjadi baik dalam memberikan layanan publik dan proses pengambilan kebijakan. Tidak hanya itu, good governance juga akan mendorong partisipasi masyarakat dalam pemerintahan daerah, dan daklam batas tertentu kan terjalin sinergisitas antara pemerintah dan masyarakat. Dalam bahasa Piet Alexander Tallo, mantan Gubernur NTT [2003;14]:

good governance berhasil mengeluarkan pemerintah daerah dari monopoli kekuasaan, sehingga terjadi share of power dan share of responsibility dalam suatu ikatan interdependensi yang saling menunjang dalam semangat kemitraan yang tinggi. Pemerintah daerah tidak lagi menjadi agen tunggal atau aktor satu-satunya di atas panggung politik daerah.

\section{Problematika Good Governance di daerah}

Nilai-nilia good governance sebagaimana dijelaskan di atas tidak mudah diimplementasikan dalam pemerintah daerah. Penjelasan ini diperkuat oleh Novel Ali yang secara tegas mengatakan bahwa 'tidak ada pemerintahan daerah bersih di masa lalu'. Ungkapan ini tentu mengandung kebenaran, apabila kita menelusuri proses penyelenggaraan pemerintah daerah. Sejumlah fakta politik bisa dijadikan bukti bahwa good governance di daerah menemukan jalan buntu. Pertama, rakyat tidak bisa berpartisipasi langsung dalam proses demokrasi, melainkan harus lewat mekanisme perwakilan. Mekanisme perwakilan itu sendiri tidak sepenuhnya bisa memperjuangkan aspirasi rakyat.

Kedua, pemerintah daerah seorang berjalan sendiri (one man show) dalam pengelolaan pemerintahan daerah, sehingga pemerintah daerah berfungsi gusti sementara rakyat sekedar kawula. Ketiga, posisi warga negara di belakang pemerintah daerah. Akibatnya, rakyat menjadi sangat pasrah atau tergantung kepada pemerintah, selain itu, rakyat pun merasa tidak perlu berperan aktif dalam pengelolaan pemerintah daerah [Ali,2000].

Keempat, tidak adanya pemisahan yang jelas antara kekayaan dan sumber milik rakyat dan milik pribadi. Kelima, tidak ada aturan hukum yang jelas dan sikap pemerintah daerah yang tidak kondusif untuk pembangun daerah. Keenam, belum utuhnya pengakuan pluralisme masyarakat, yang dapat dilihat dari keikhlasan pemerintah nasional menyerahkan wewenang pemerintahan kepada pemerintah lokal [Imawan,2005;48]. Ketujuh, meluruskan jalan reformasi dalam perspektif tata pemerintahan daerah yang baik diperhadapkan dengan fakta bahwa saat ini kita mewarisi suatu kultur pemerintahan yang berorientasi kekuasaan dan bukan pelayanan. Kedelapan, korupsi tidak lagi dilakukan oleh individu yang ingin memperoleh uang cepat, namun juga oleh lembaga-lembaga politik dan pemerintah daerah sebagai upaya untuk menghidupi lembaganya [Pratikno,2003;8]. Terakhir, nuansa KKN dan pungli senantiasa mewarnai aktivitas public service, dimana masyarakat dan pelaku usaha yang seharusnya punya hak mendapatkan layanan, justru tak jarang harus melayani 
pejabat atau aparat daerah, dalam wujud pemerian konpensasi berupa uang [Bastian, 2000].

Daftar tersebut hanyalah bagian kecil dari problematika pembangunan pemerintah yang bersih di daerah. Ironisnya lagi adalah, para aktor yang selama ini menyuarakan pemerintah yang bersih terkadang kontra-produktif. Kita bisa menyaksikan betapa banyak pemerintah daerah, birokrasi, dan politisi daerah yang terlibat dalam perilaku korupsi, kolusi, dan nepotisme. Hal ini menunjukkan bahwa persoalan pemerintahan yang bersih merupakan persoalan sentral yang menjadi perhatian banyak pihak.

Karena itu untuk membangun sistem pemerintah yang bersih di daerah membutuhkan dua hal. Pertama, sistem yang akan mendukung berdirinya pilar pemerintahan daerah yang bersih, hanya bisa berjalan kalau didukung oleh aparat pemerintah atau birokrat, dengan masyarakat. Salah satu yang melanggar komitmen, tak akan jalan [Bastian, 2000]. Kedua, kombinasi dari kejujuran dan kecakapan seorang birokrat, serta sistem kelembagaan yang mendukung berjalannya mekanisme kontrol secara baik [Karseno,2000].

\section{Praktik Good Governance di Daerah}

Dalam praktiknya, semangat demokratisasi dan desentralisasi dalam tata kelola pemerintahan daerah yang baik sudah mewujud. Beberapa daerah di Indonesia telah melakukan pembaharuan dalam tata kelola yang baik. Hal ini direkam dalam laporan Building Institution for Good Governance atau The Bigg Ficture (www.bigg.or.id). Laporan The Bigg diperkuat oleh pendapat I Ketut Putra Erawan [2007;3]

telah muncul beberapa praktik yang inovatif dalam tata kelola pemerintahan daerah yang baik. Best practices ini bahkan tersebar diberbagai wilayah di Indonesia. Umumnya praktek-praktek tersebut mengindikasikan adanya kepemimpinan yang kuat dan visioner, evokatif, dan bertahap dan membutuhkan pelibatan berbagai pihak yang berkepentingan. Sebagian besar menekankan satu atau kombinasi beberapa pinsip dasar bagi suatu tata pemerintahan yang baik. Pilihan prinsip dasar tersebut sangat tergantung konteks lokalitas pemerintahan daerah masingmasing.

Kutipan ini menarik untuk ditelaah dengan mengkonfrontasikan dengan fakta lapangan. Dalam realitas pemerintahan daerah, tidak bisa dipungkiri bahwa pilihan prinsip good governance sangat tergantung dengan komitmen politik pemerintahan daerahnya. Sebagai ilustrasi, di Kabupaten Bangkalan, Jawa Timur, sejak tahun 2002 pemerintah mempraktekan mekanisme transparansi dan penyusunan ABPD melalui lembaga Forum Koordinasi dan Sinkronisasi Perencanaan Pembangunan (FKSPP). Kelompok-kelompok NGO lokal diikut sertakan dalam penyusunan dan pembahasan APBD. Sedangkan di Gunungkidul, DIY, pelibatan perempuan dalam proses penganggaran sangat giat dilakukan pemerintah daerah [Basir, 2006;97-132]. 
Apa yang terjadi di Bangkalan dan Gunungkidul menunjukkan bahwa prinsip transparansi dan partisipasi warga dalam penyusunan anggaran di daerah sudah mulai jalan. Sedangkan di Bulukumba, NGO berhasil memaksa pemerintah daerah untuk transparan dalam penerimaan PNS. Transparansi sengaja digulirkan agar pemerintah daerah terbuka dalam proses rekrutmen. Di Solo dalam melakukan pelayanan publik dalam hal kartu tanda penduduk, akta kelahiran, dan akta kematian mengoptimalkan media sosialmelalui whatsapp, sms, dan omline. Tujuannya tentu saja memberikan layanan yang murah, efisien, efektif, dan transparan [Prasetyo,2016].

Penjelasan singkat ini mengisyaratkan bahwa pemerintahan daerah telah membuka ruang partisipasi, transpransi, dan efisien dalam tata kelola pemerintahan daerah. Prinsip good governance ternyata diberlakukan oleh pemerintah daerah sesuai dengan lokalitasnya. Bulukumba dan Bangkalan menerapkan proses transparansi, sedangkan Gunungkidul menerapkan prinsip partisipasi dalam penganggaran. Sedangkan, di Solo dalam layanan publiknya, menerapkan prinsip transparasi, efisien, dan efektif. Karena itu Solo mencoba menkombinasikan tiga prinsip good governance dalam layanan publik.

Implementasi prinsip good governance merupakan cara untuk membangun kepercayaan baru institusi pemerintahan dihadapan masyarakat. Pandangan Hans tentu saja benar, karena memungkinkan terjadinya interaksi antara pemerintah dan masyarakat dalam proses politik di daerah. Selain itu, tuntutan masyarakat terhadap transparansi dalam pengelolaan pelayanan publik juga terus diupayakan. Ambil contoh, dalam pengurusan IMB atau pun perijinan di loket pelayanan sudah dipasang syarat yang harus dipenuhi hingga biaya yang harus dikeluarkan. Model pelayanan seperti ini mendapat sambutan masyarakat.

Tampilan cerita sukses dalam menerapkan prinsip good governance ini bisa menjadi titik masuk bagi munculnya sebuah tata pemerintahan yang demokratis. Bagi sistem, maka penerapan prinsip-prinsip tata pemerintahan yang baik akan memberikan fondasi bagi munculnya aturan main yang disepakati bersama serta berkembangnya sebuah pola interaksi antara berbagai aktor yang seimbang. Bagi pemerintahan daerah, maka masingmasing prinsip tersebut memiliki signifikansi tersendiri [Erawan, 2007;3].

\section{a. Tidak bisa dirawat dan berkelanjutan}

Capaian disejumlah daerah dalam menerapkan good governace patut diapresiasi dan ditumbuh-kembangkan. Logikanya sangat sederhana yakni kebanyakan program yang baik tiba-tiba hilang begitu saja seiring dengan pergantian kepala daerahnya. Sebagai ilustrasi, masa kepemimpinan Untung Wiyono telah banyak memberikan inovasi dalam layanan publik dengan cara berkoalisi dengan masyarakat untuk menghadapi birokrasi yang lamban [Widiyahseno, 2015; 193]. Hasilnya, adalah Sragen menjadi salah satu kabupaten yang terdepan di Jawa Tengah dalam melakukan perubahan dalam tata kelola pemerintahan daerah. 
Pengalaman yang dilakukan I Gede Winasa selaku bupati Jembarana.Winasa merupakan potret bupati yang sempat menjadi ikon dan teladan reformasi pemerintah daerah. Bupati Winasa meraih kejayaan ganda (reformasi dan kekuasaan) [Eko, 2013;2] karena berhasil melakukan perubahan dalam tata kelola pemerintahan daerah. Reformasi birokrasi, pemberantasan korupsi, keberpihakan kepada masyarakat miskin, dan keterlibatan masyarakat sipil dalam perencanaan pembangunan daerah [Eko, 2007; 60] merupakan bukti keberhasilan Winasa dalam menata pemerintahan yang baik. Namun, diakhir masa jabatannya, ternyata kekuasaan itu runtuh secara dramatis.

Semua kebanggaan yang pernah ada, hancur berantakan. Winasa pun terlilit dengan korupsi. Jadi, apa yang dialami oleh Winasa juga terjadi Untung di Sragen. Kedua figur pemimpin daerah ini, ternyata berakhir di penjara. Implikasinya adalah semua program yang pernah ada dan membawa 'nama baik dan harum' hancur berantakan. Para penerus di pemerintahan mencoba menghindar atau mencampakkan program tersebut dan diganti dengan program baru.

Pada fase inilah cerita sukses dalam mengelola pemerintahan daerah yang bersih mengalami titik rawan. Program sebelumnya memang tidak 'dibajak', tetapi diakhiri secara dramatis oleh pemimpin baru. Persoalan adalah terkadang pemimpin yang baru ini juga tidak mempunyai kapasitas yang mumpuni, bahkan minus program kerja. Mereka terpilih sebagai pemimpin bukan karena kapasitas dan program kerja tetapi karena menebar uang. Akibatnya adalah daerah tersebut mengalami kemudaran dalam tata kelola pemerintahan yang baik. Kasus ini sudah banyak terjadi. Pemimpin baru tidak bisa menyamai apalagi melebihi pemimpin sebelumnya. Inilah ini disebut Hatta [1960;23] suatu masa besar dilahirkan abad. Tetapi masa besar itu menemui manusia kecil.

Kritik Hatta terhadap pemimpin daerah yang berkinerja buruk, biarlah menjadi renungan kita bersama. Siapa tahu, pemimpin seperti ini segera berlalu, dan diganti dengan pemimpin yang berkapasitas dan berkarakter inovatif, berjiwa besar, dan mau mengabdikan dirinya kepada masyarakat. Jenis kepala daerah ini sudah tentu yang siap menyapa masyarakat dengan program, membuka pemerintahannya dengan menerapkan keterbukaan informasi publik, mendengar segala keluhan warganya melalui website dan SMS center, atau membuat dialog publik melalui RRI dan coffe morning bersama wartawan dan masyarakat [Mukti dan Mujiyanto, 2009;37-39].

Semua ini dilakukan dalam kerangka membangun sistem pemerintahan daerah yang baik. Membangun sistem pemerintahan daerah yang baik dan berkelanjutan ternyata bukanlah perkara mudah dan gampang. Karena itu memerlukan sebuah sistem dan kelembagaan yang baik. Harapannya adalah agar pemerintahan daerah yang baik ini bisa terlembaga.

\section{b. Membangun Good Governance di Era Desentralisasi}

Pewacanaan dan praktik good governance perlu terus di bangun secara terus-menerus 
dalam era desentralisasi. Karena begitu penting bagi daerah, maka pemerintah pusat, lembaga donor, NGO, maupun perguruan tinggi saling bahu membahu dalam mendorong praktik good governance di daerah. Peran pemerintah pusat sangat jelas dalam membuat regulasi mengenai tentang pemerintah yang bersih bebas KKN. Lembaga donor dan NGO sangat massif melakukan pendampingan kepada pemerintah daerah dalam usaha menyuntikkan prinsip-prinsip good governance. Sementara perguruan tinggi, selain menjadi mitra, fasilitator, juga dituntut untuk melakukan pendokumentasian praktik good governance di daerah.

Sinergisitas dalam mendorong dan membangun praktik good governance di daerah sangat diperlukan karena beberapa hal. Pertama, penciptaan praktik good governance bukan hanya melalui usaha membentuk pemerintahan yang baik dan bersih saja, melainkan juga membuat bagaimana agar sistem dan tatanan yang ada dapat berjalan dengan sendirinya. Kedua, membumikan good governance di era desentralisasi ini diperlukan transparasi pemerintahan, partisipasi masyarakat dalam pemerintahan, sistem akuntabilitas penyelenggara pemerintah daerah yang baik dan memadai, sehingga dapat diterima masyarakat. Ketiga, birokrasi daerah juga dituntut bekerja efisien, efektif, kompetitif, antisipatif, aspiratif, produktif, serta pelayanan yang bermutu tinggi. Sekaligus merupakan birokrasi daerah yang tidak membuka peluang korupsi, kolusi dan nepotisme [Ali, 2000].

Keempat, diperlukan komitmen yang kuat dari semua komponen pemerintah daerah untuk berani berkata: enough is enough terhadap semua penyimpangan. Perlu dibangun suatu permufakatan politik untuk menyatakan permusuhan abadi terhadap segala bentuk KKN. Hanya dengan jalan itu, tata kelola pemerintahan daerah yang baik bisa berjalan. Kelima, membumikan good governance ungen untuk dilaksanakan di daerah, mengingat sebahagian besar wewenang pemerintah telah diserahkan kepada pemerintah daerah dan masyarakat daerah. Kedudukan kepala daerah dan DPRD sangat strategis dalam menciptakan Indonesia yang yang bersih dan kuat. Keenam, pemerintah daerah yang kuat, efektif dan akseptabel menjadi peluang emas untuk meluruskan jalan reformasi, hanya terwujud apabila dikelola secara cerdas dan kreatif dengan berani membuat format baru pemerintahan sebagai perwujudan tata pemerintahan yang baik [Tallo, 2003;29].

Terakhir, membumikan good governance dalam era desentralisasi harus dilakukan melalui tekanan eksternal dari luar birokrasi atau pemerintahan daerah, yakni melalui pemberdayaan masyarakat sipil untuk memperbesar partisipasi berbagai warga negara dalam penyelenggaraan pemerintah daerah [Effendi,2005;5] yang baik dan bersih. Selain tekanan partisipasi, pemerintah daerah beserta birokrasi daerah juga perlu dipaksa untuk melakukan pertanggungjawaban secara vertikal yakni pemerintah kepada masyarakat serta pertanggungjawaban horizontal yakni pemerintah daerah kepada DPRD.

Selain persoalan partispasi dan pertanggungjawaban, membumikan pemerintahan daerah yang baik dan terbuka bisa diwujudkan dengan 
mengaktualisasikan lima hak warga negara. Pertama, hak warga negara untuk memantau dan mengamati perilaku pejabat publik daerah. Kedua, hak warga negara untuk mendapatkan informasi. Ketiga, hak warga negara untuk untuk dilindungi dalam mengungkap fakta dan kebenaran. Keempat, hak warga negara untuk mengajukan keberatan. Kelima, hak/kebebasan berekspresi yang diwujudkan dengan kebebasan pers yang berkualitas [Santoso,2003;10].

\section{Kesimpulan}

Ternyata untuk membangun good governance dalam era desentralisasi merupakan pekerjaan yang tak kunjung usai. Karena itu, menjadi tugas kolektif sesama anak bangsa dalam mendorong, membangun, dan membumikan good governance di daerah. Prinsip-prinsip good governance sangat universal sifatnya karena itu pemerintah daerah perlu mengadopsi dan mengimplementasikannya secara universal juga. Konsepsi good governance bisa diibaratkan dengan McDonald's dalam era globalisasi. Dimanapun McDonald's berada ada standarisasi rasa yang konsisten. Aroma rasanya yang ada di Amerika, di Istambul, Jepang, dan Jakarta relatif sama [Mallarangeng, 2014;17].

Itu artinya pemerintah daerah yang baik akan dituntut untuk bersandar pada aturan yang sama. Sebab pemerintahan daerah harus bisa mengelola pemerintahan yang bersih dan berwibawa serta mampu memecahkan masa-masa daerah. Karena itu pemerintah yang kuat dan pemerintahan yang baik akan membawa kesejahteraan [Abeng, 2012; 254] bagi masyarakat daerah. Inilah tugas yang paling hakiki dari pemerintahan daerah yakni memberikan layanan publik dan kesejahteraan kepada masyarakat secara universal serta memiliki pertanggungjawaban politik baik kepada lembaga legislatif daerah maupun kepada masyarakat.

\section{Daftar Pustaka}

Abeng. Tanri. 2012. Managing The Nation With Tanri Abeng. Jakarta. Alex Media Komputindo

Ali, Novel. 2000. 'Mewujudkan Pemerintahan Bening di Negeri Kita' Kedaulatan Rakyat, 2 Maret.

Basir, Wahyu. 2006. Keindahan Yang Menipu. Jogjakarta, IDEA.

Bastian, Agus. 2000. 'Pemerintah Bersih, Dimulai dari Siapa?' Kedaulatan Rakyat, 23 Maret

Effendi, Sofian. 2005. ' Membangun Good Governance: Tugas Kita Bersama' Makalah yang disampaikan di UGM, Yogyakarta, 26 Desember.

Effendi, Tadjuddin Noer. 2002. 'Membangun good governance melalui pembangunan berbasis masyarakat' Dipersiapkan untuk diskusi panel dilaksanakan Lembaga Pengkajian Pembangunan Sosial Melati Bhakti Pertiwi di Jakarta Kamis 4 Juli

Eko, Sutoro. 2007. 'Dari Daerah Budiman Menuju Daerah Sejahtera' MANDAROTY, Vol.3/Tahun 3.

Eko, Sutoro. 2013. Drama Reformasi: Kejayaan dan Keruntuhan Bupati I Gede Winasa di Jembarana, Jogjakarta, UGM.

Erawan, I Ketut Putra, dkk (ed). 2007. Merajut Good Governance dalam 
Penyelenggaraan Pemerintah

Daerah, Jakarta, Bank Dunia.

Hardjasoemantri, Koesnadi. 2003. 'good governance dalam pembangunan Berkelanjutan di Indonesia' Makalah Untuk Lokakarya Pembangunan Hukum Nasional ke VIII di Bali, tanggal 15 Juli.

Hatta, Moh. 1960. Demokrasi Kita. Jakarta, Panji Masyarakat

Imawan, Riswandha. 'Desentralisasi, Demokrasi, dan Pembentukan Good Governance dalam Syamsuddin Haris (ed). 2005. Desentralisasi dan Otonomi Daerah,Jakarta, LIPI Press

Karseno, Arief Ramelan. 2000. 'Pemerintah yang Bersih, Mungkinkah?' Kedaulatan Rakyat, 25 Maret

Mallarangeng, Andi. 2014. Inferno: Neraka di Bumi, Betulkah?. Jakarta. Freedom Institute.

Mardiasmo, 2002. Otonomi dan Manajemen Keuangan Daerah. Jogjakarta, ANDI

Mukti, Rusdiono dan Mujiyanto. 2009. Berani Tidak Populer, Jakarta, Sinar Harapan.

Prasetyo, Erwin Edi. 2016. 'Solo Optimalkan Media Sosial' Kompas, 19 Desember

Pratikno, 2003. 'Jalan Berbelit Menuju Pemerintah Yang Baik' Disampaikan dalam Seminar Meluruskan Jalan Reformasi, UGM, Jogjakarta, 26-27 September.

Pratikno, 2005. 'Good Governance dan Governabilty' JSP, Vol.8. No.3 Maret.

Santoso, Mas Ahmad. 2003. 'Agenda Pembaharuan Hukum dalam Rangka Mewujudkan Pemerintah
Yang Baik' Disampaikan dalam Seminar Meluruskan Jalan Reformasi, UGM, Jogjakarta, 2627 September.

Tallo, Piet Alexander, 2003. 'Tata Pemerintahan Yang baik: Refleksi dan Pengalaman', Disampaikan dalam Seminar Meluruskan Jalan Reformasi, UGM, Jogjakarta, 2627 September.

Widiyahseno, Bambang. 2015. 'Inovasi Bupati di Ruang Demokrasi: Upaya Membangun Kesadaran Inovasi Birokrasi' dalam JSP, Vol.18, No.3 Maret. 